\title{
The Future Perception of Gifted Individuals and Society about Gifted Individuals $^{1}$
}

\author{
Betül BÜYÜK², Eyüp ÇELİK
}

\begin{tabular}{l} 
ARTICLE INFO \\
\hline Article History: \\
Received 27.11 .2020 \\
Received in revised form \\
23.01 .2021 \\
Accepted \\
Available online 01.04 .2021
\end{tabular}

\begin{abstract}
This study examined the future perception of gifted individuals and society about gifted individuals. The study was carried out with a phenomenological approach, one of the qualitative research methods. The sample of this study was gathered from gifted students and adults in İstanbul and Kocaeli. The result of the research exhibits that gifted individuals were perceived as researcher-type people by both themselves and adults. Also, there is a need to improve gifted students' educational process and reveal their potential skills. In addition, although people generally have a positive perspective on the future of gifted young people, it is frequently emphasized that the conditions they live in are worrisome.
\end{abstract}

CIJERE. All rights reserved

Keywords: ${ }^{2}$ Gifted, society, future perception, education.

\section{INTRODUCTION}

How society perceives gifted individuals, and their future can be a guide for both increasing the social productivity of gifted individuals and raising them well. To get the answers to the question of how gifted individuals are perceived by society, it is necessary to look at the definition of this concept, the history and the current situation of the practices in our geography. Individuals whose abilities appear in one or more areas are well above the norms of their peers are called gifted individuals. "These potential areas can be intellectual, creative, artistic, leadership, as well as in specific academic fields such as language arts, math, or science (NAGC, 2018)." Although chronologically at the same age, gifted children may differ from nongifted peers in terms of cognitive, emotional, or any psychological and developmental characteristics (Wood, 2006). In Turkey, realizing gifted students are different from their peers and taking steps for these individuals are based on the time of the Ottoman Empire until the students in the Enderun School (Akkutay, 2004). In the ongoing process, education policies and development plans were prepared for the gifted students in the first years of the republic (K1liç, 2015). Considering the quality of the meetings and plans, although the awareness of gifted individuals in the society and the high number of meetings held for gifted students stand out; there is no concrete action plan.

Today, Science and Art Centers (BILSEM) were established in 1995 to support the education of gifted individuals in our country, and they support the identification of gifted students and their education processes (MEB, 2016). Although the contributions of BILSEMs enable realizing of gifted individuals, the real potentials of these students and their perspectives on life cannot be fully understood. Students who are selected to BILLEM at primary, secondary, and high school levels work on certain days of the week in line with their abilities. These studies are an opportunity for students to discover themselves and to work in areas they enjoy. On the other hand, gifted students are an opportunity to accelerate the development of our country, and their work in their field can make our country more independent in economic, political, and many ways. Gifted students are considered as students with the potential to shape the future (Ogurlu, 2016). However, in our country, the career path of gifted students are not followed. Since there are no statistics about to what extent the potentials of gifted individuals are employed, it is also impossible to evaluate the advantages and disadvantages of these individuals. Considering researches in Turkey, Science and Art Centers (BILSEM) and schools focus on the academic success of these students and their academic development. It is seen that no study has been done on issues such as how these individuals contribute to society after their graduation, their future expectations, and what are the future expectations of the society on these individuals. When the future perspective is considered as a variable that increases the current success of the individual (Lens \& Rand, 2000), researches on this subject show that the perspective is

\footnotetext{
${ }^{1}$ The summary of this research was presented as a verbal statement at the International Education Management Forum - EYFOR XI.

2 MA. betul.buyukk@gmail.com, 0000-0003-2496-1474, Sakarya Universtiy

${ }^{3}$ Corresponding e-mail: eyupcelik@sakarya.edu.tr, 0000-0002-7714-9263,Sakarya Universtiy
} 
important for the future success of the individuals (Ogurlu, 2016). Besides, it is stated that the future perspectives and passions of gifted children directly affect their hopeful situation (Lovecky, 1992, cited in Ogurman, 2016). In a study, academic achievement and future perspectives were compared and the relationship between them was found to be positive (Cartron-Guerin \& Levy, 1980 cited in Ogurman, 2016). As Lens and Rand (2000) stated, gifted people's foresight of the future is clearer and more advanced than their peers due to their cognitively ahead of their peers. Therefore, considering the differentiating characteristics of gifted students from their peers, it is expected what these students think about themselves and their future will differ according to their peers. People's perspective to gifted students, their expectations from them, and their orientation to gifted individuals leave a positive or negative imprint on these individuals. At this point, as a result of a comprehensive review in the literature, there are not many studies on the perspectives of the society on these individuals and one of the most comprehensive studies conducted close to this subject is the study of Brynt (2010) with school administrators; In this study, administrators' attitudes and perceptions towards students were examined. The research proves how effective the perception of the leader is in influencing the perceptions of students who are in the decision-making process. In the research conducted by Jolly and Matthew (2012), 53 studies published on the parents of gifted students since 1983 were examined and it was concluded that parental attitudes have a strong effect on children's success and perceptions. It is clear that the people who touch the students most directly affect the success and perceptions of the students. Stewart (1999) that gifted children often fall between personal goals and society's expectations; He mentioned that he felt pressure from his parents and teachers to achieve everything.

\section{Present Study}

Every reaction the students get from the people they are in contact with and the expectations against the gifted, the decisions to be taken about these individuals and the political practices will be effective in forming their perspectives for the future. Based on this assumption, researching future perceptions about gifted individuals will contribute to the society's shaping expectations from these individuals. For this reason, in this study, the perceptions of gifted individuals about their own future and the perspective of their society on the future of gifted individuals were tried to be examined. Learning the perspectives of individuals with high potential will contribute to determining the steps to be taken for education policies, economic investments, and improvement of living conditions for these individuals. Getting insight about the views of these individuals will contribute to the creation of a political perspective to benefit more from the potential of gifted individuals that will contribute to the society and will remove the uncertainty about the future of the gifted individual. Besides, tension and competition between countries are increasing in the century we live in. Countries competing for research and development. Also, Turkey need to keep up with this development to protect both national and international interests. For this reasons, our greatest resource is our young population with high potential and these individuals should be educated and reintegrated into society.

\section{METHOD}

This research was conducted with phenomenology design, which is a qualitative research method. In this study, the phenomenon was determined as the perspective of gifted students on their future and society's perspective on the futures of gifted individuals.

\section{Study Group}

The sample of the study consists of 173 gifted students studying at high school level in Istanbul and Kocaeli and 148 adults from different segments of the society living in the same provinces. In the sample of the study, criterion sampling was used for the student group. While selecting the sample, the criterion was that the students were gifted. For the data obtained from the society, the sample was also determined with the appropriate sampling method. $51 \%$ of gifted students participating in the study are male $(\mathrm{N}=89), 49 \%$ are female $(\mathrm{N}=84) ; 35 \%(\mathrm{~N}=52)$ of the data collected from adult individuals are men and $65 \%(\mathrm{~N}=96)$ of them are women.

\section{Data Collection}


The research data were collected by using semi-structured forms with the same content prepared to be applied to students and adults in the study group. The data collection process was carried out by distributing forms to students and adults and collecting them back. Before distributing the forms, the study groups consisting of adults and students were informed about the subject, and during the implementation, situations that would guide the study groups and affect the course of the research were avoided. Participants filled out the forms individually. Regarding research cases, "In which field should gifted work?" "What are your expectations about the education process of gifted individuals?" "What do you think about the future of gifted individuals" questions were asked.

\section{Data Analysis}

The data was analyzed with the content analysis method. After all the data were collected, the answers given were categorized.

\section{FINDINGS}

\section{"In which field should gifted individuals work?" Findings Obtained from the Answers Given to the Question}

The answers of gifted students and adults participating in the study, "In which field should gifted individuals work?" The answers they gave to the question were evaluated in general, and the answers are analyzed according to the personality types mentioned in Holland's Personality Theory. According to Holland's personality theory, there are 6 types of personality; realistic, researcher, creative, social, entrepreneur, regular type (Campbell, \& Holland, 1972). The answers obtained according to Holland's personality theory and sample answers that these typologies do not reflect are shown in Table 1 and Table 2.

\section{Gifted students who identify a specific profession}

Holland's typologies:

Realistic Type: Sport (2), aviation (1),

Researcher Type: Medicine - Health (10), engineering (9), Science (14), psychology (1), technology (3)

Creative Type: Art (6), areas that require creativity (4),

Social Type: Education Sector (3), professions socially beneficial (3)

Entrepreneurial Type: Professions that require leadership and management (12), Entrepreneurship (2), law or politics (4), International relations (1)

Regular Type: Military field (1)

\section{Gifted students who anticipate orientation without specifying a specific area}

- The field of potential (33), in different areas from other people and must be active (3)

\section{Gifted students who argue that orientation is not true}

- They can work in any field (14), they do not have to work (2), and the field they are interested in (37) 
Table 1. Sample Gifted Participant Views Based on Determining the Themes

\begin{tabular}{|c|c|}
\hline Realistic Type (3) & "Aviation" \\
\hline Creative Type (10) & $\begin{array}{l}\text { "They should do jobs where they can use their own creativity as much as } \\
\text { possible without being constrained by a boss. For example, in my opinion, } \\
\text { someone with a high potential should never be an engineer, because from that } \\
\text { moment on he is no different from a calculator." }\end{array}$ \\
\hline Social Type (6) & "Community Service" \\
\hline Entrepreneurial Type (19) & $\begin{array}{l}\text { "Since I think that individuals who are named as gifted have more open } \\
\text { consciousness and perceptions than other individuals, I think that it would be } \\
\text { appropriate for such labeled individuals to work in higher positions, that is, in a } \\
\text { way that manages and supervises others." }\end{array}$ \\
\hline Regular Type (1) & "Soldier" \\
\hline
\end{tabular}

Student answers and themes reached without specifying a specific profession

\begin{tabular}{l|l}
\hline Field of talent (33) & $\begin{array}{l}\text { "Gifted individuals should work in areas where they are gifted, gifted is a } \\
\text { concept divided into superior potential branches. For example, I want to be a } \\
\text { marine biologist. " }\end{array}$ \\
\hline $\begin{array}{l}\text { In different areas from } \\
\text { other people and must be } \\
\text { active }\end{array}$ & $\begin{array}{l}\text { "Gifted individuals receive a different education than others and as a result of } \\
\text { this education, they should work in different professions than others." }\end{array}$ \\
\hline
\end{tabular}

Gifted students who argue that orientation is not true

\begin{tabular}{l|l}
\hline $\begin{array}{l}\text { They can work in any } \\
\text { field (14) }\end{array}$ & $\begin{array}{l}\text { "I think every person is free to choose his own profession; whether gifted or not. } \\
\text { On the contrary, then they give the highest yield. }\end{array}$ \\
$\begin{array}{l}\text { The field they are } \\
\text { interested in (37) }\end{array}$ & $\begin{array}{l}\text { "I think they should work on their favorite profession; do what they enjoy. } \\
\text { Because if they do what they love, they can be useful in that area." }\end{array}$ \\
$\begin{array}{l}\text { they do not have to work } \\
\text { (2) }\end{array}$ & $\begin{array}{l}\text { "I don't think they have to work in a certain profession. They can sit in their } \\
\text { homes. " }\end{array}$ \\
\hline
\end{tabular}

\section{Adults who identify a specific profession}

Holland's typologies:

Realistic Type: Agriculture (1), sports (2)

Researcher Type: Science, technology, Research \& Development (50), Engineering (18), MedicineHealth (16)

Creative Type: creative jobs (1), Art (16),

Social Type: Academician-education (13), Social fields (4), Philosophy-sociology (2) 
Entrepreneurial Type: Politics (3), Management-Leadership (6), advertising (1), entrepreneurship (1) Regular Type:

\section{Adults who anticipate orientation without specifying a specific area}

According to their ability (37), Areas that beneficial for humanity (3), there is a need in every field (5)

\section{Adults who argue that orientation is not true}

It must be a job that they will be happy to do. (13), the field they are interested in (19)

Table 2. Sample Adult Participant Views Based on Determining the Themes

\begin{tabular}{|c|c|}
\hline \multicolumn{2}{|c|}{ Answers of adults and themes reached indicating a specific profession } \\
\hline Realistic Type (3) & "Agriculture", "Sports" \\
\hline Investigator Type (84) & "Nano technology, medicine, genetics" \\
\hline Creative Type (17) & "They can work in any profession that requires creativity" \\
\hline Social Type (19) & $\begin{array}{l}\text { "They usually choose science related professions, but I think it is more important for } \\
\text { them to choose social professions that are related to the real people and touch people." }\end{array}$ \\
\hline Entrepreneurial Type (11) & $\begin{array}{l}\text { "Management" } \\
\text { "Senior manager in private sector or government institutions." }\end{array}$ \\
\hline Regular Type (0) & - \\
\hline
\end{tabular}

Adult answers and themes reached without specifying a specific profession

\begin{tabular}{l|l}
\hline According to your ability (37) & $\begin{array}{l}\text { "They should work in a profession where they can use his talent and capacity at the } \\
\text { highest level, because we need people who will rise to the top of every profession and } \\
\text { carry that profession forward." }\end{array}$ \\
\hline There is a need in all areas (5) & $\begin{array}{l}\text { "I don't want to make any professional restrictions. I want them to be accessible in all } \\
\text { areas of life. " }\end{array}$ \\
$\begin{array}{l}\text { Areas that will benefit } \\
\text { humanity (3) }\end{array}$ & "They should work in every field that benefits humanity." \\
\hline
\end{tabular}

Adults who argue that orientation is not true

They should choose himself "Should work in the field of interest."

according to his interests (19).

The area they will love to do

"They should work in the area they think they will be happy with."

Considering the predicted answers and the themes reached without specifying a specific profession, it was seriously repeated that gifted students should choose a profession in line with their abilities. While these numbers were 37 in the answers given by adults, they were repeated 33 times in the answers given by gifted students. While the students thought that these individuals should choose an extraordinary and active profession; adults have emphasized on professions that will be beneficial to society.

Apart from these, the ideas stating that it is not right to predict and mold professionally for gifted students have been repeated many times. The most striking answer in this category was that students should 
choose their profession according to their interests, and this idea was repeated 19 times in adults, and 37 times in the answers of gifted students.

"What are your expectations about the education process of gifted individuals?" Answers to the Question

\section{Findings from the Answers of Gifted Student Participants}

"What are your expectations about the education process of gifted individuals?" The answers given by the gifted student participants to the question were examined and sample answers regarding the themes reached are presented in Table 3.

Table 3. Sample Answers and Themes of Gifted Students Participating in the Research

\begin{tabular}{l|l}
\hline Skill areas (63) & "Trying to complete the missing aspects of individuals is a ridiculous move.
\end{tabular} Of course, students should receive basic education in necessary subjects. However, it is nonsense to expect students to be good in every aspect. The individual should improve himself / herself in areas where he / she is good and educational institutions should support the individual."

\begin{tabular}{l|l}
\hline $\begin{array}{l}\text { The quality of the } \\
\text { education (91) }\end{array}$ & $\begin{array}{l}\text { "To get a more specific education, to learn more new information in a short } \\
\text { time" }\end{array}$ \\
\hline Inclusive skills for life (10) & $\begin{array}{l}\text { "Education life is of great importance for individuals. During education, not } \\
\text { only the curriculum is required academically, but also to raise a better person. } \\
"\end{array}$ \\
\hline $\begin{array}{l}\text { There is no need for } \\
\text { extraordinary pressure or } \\
\text { training, they can find their } \\
\text { own way. (11) }\end{array}$ & "There should not be too much pressure, they are human after all, but they \\
\hline
\end{tabular}

When Table 3 is examined, it can be said that more emphasis is placed on the quality of the training in the answers received from gifted participants (91). The way the courses are given and the richness of their content are among the criteria that students take into account. In addition, immediately after the quality of the education, the desire of the students to turn to the talent areas draws attention (63). It is also understood that some gifted students need support in developing inclusive skills for life (10). Finally, it is seen that there is a group of students who think that gifted students do not need an education other than ordinary education and that they can find their own way under any circumstances (11).

\section{Findings from the Answers of Adult Participants}

"What are your expectations about the education process of gifted individuals?" The answers given by the adult participants to the question were examined and sample answers regarding the themes reached are presented in Table 4 . 
Table 4. Sample Answers and Themes of Adult Participating in the Research

\begin{tabular}{l|l}
\hline Skill areas (76) & $\begin{array}{l}\text { "An education process that supports their strengths more, rather than focusing on } \\
\text { their development potential, will be more effective for such individuals." }\end{array}$ \\
\hline $\begin{array}{l}\text { Quality } \\
\text { Education (65) of }\end{array}$ & $\begin{array}{l}\text { "They should receive a very privileged education by the state. An education that will } \\
\text { maximize both academic and life skills." }\end{array}$ \\
\hline $\begin{array}{l}\text { Inclusive Skills for } \\
\text { Life (11) }\end{array}$ & $\begin{array}{l}\text { "The behavior of gifted individuals can vary widely. For example, some individuals } \\
\text { are not accepted by the society. Education should be given by considering all } \\
\text { behaviors. These people should not be removed from society. " }\end{array}$ \\
\hline $\begin{array}{l}\text { Psychological } \\
\text { Support (6) }\end{array}$ & $\begin{array}{l}\text { "It should be trained with a program that will take their development even higher } \\
\text { and with educators who can mentor them and with individuals like them. They must } \\
\text { be in a school or institution that supports this. Because, if they are not blocked in areas } \\
\text { suitable for them, they will find their way. However, they should be supported and } \\
\text { observed not only in academic but also in psychological social areas in this process, } \\
\text { especially during adolescence. " }\end{array}$ \\
\hline $\begin{array}{l}\text { Psychoeducation } \\
\text { for Families (1) }\end{array}$ & $\begin{array}{l}\text { "Identifying at an early age and providing support and opportunities to support not } \\
\text { only children but also their families' development. Families should not be left alone in } \\
\text { this regard. " }\end{array}$ \\
\hline $\begin{array}{l}\text { Socio-Cultural } \\
\text { Activities (2) }\end{array}$ & $\begin{array}{l}\text { "They should be directed to at least one social activity outside this field in order to } \\
\text { support their social-emotional development." }\end{array}$ \\
\hline
\end{tabular}

In the Table 4 , it is stated that the primary expectation of adults about the education process of gifted students is that students should receive education in line with their ability areas (76). The quality of education (65) was found to be in the first place in the results of the students, while it was in the second place in the answers of the adults. In addition, the fact that the students acquired the inclusive skills that will prepare them for life in the education process was an item that adults also emphasized at a similar rate (11). In addition to this item, while there are adults who think that there should be psychological support in addition to this item (6), we can see that psychosocial support is not mentioned in students. Lastly, it is noteworthy to mention that parents should be given psychoeducation (1) and socio-cultural activities should be included in education (1).

\section{"What do you think about the future of gifted individuals?" Answers to the Question}

\section{Findings from the Answers of the Gifted Student Participants}

"What do you think about the future of gifted individuals?" The answers given by the gifted student participants to the question were examined and sample answers regarding the themes reached are presented in Table 5. 
Table 5. Sample Answers and Themes About Expectations of Gifted Students for Their Future

\begin{tabular}{|c|c|}
\hline Successful with adequate support (31) & $\begin{array}{l}\text { "If the right education is given, it can stand out more in } \\
\text { the society." }\end{array}$ \\
\hline Unconditionally successful (36) & $\begin{array}{l}\text { "Gifted individuals are often successful in their lives; I } \\
\text { think that in the future I will both be successful and } \\
\text { become famous. I also believe that I will be happy doing } \\
\text { what I love." }\end{array}$ \\
\hline Hopeless due to the conditions (16) & $\begin{array}{l}\text { "I think they will go unnoticed in Turkey. They do not } \\
\text { benefit the world because they are not generally well } \\
\text { guided." }\end{array}$ \\
\hline $\begin{array}{l}\text { Although they are successful, there will } \\
\text { be problem about their social } \\
\text { development and adaptation (9) }\end{array}$ & $\begin{array}{l}\text { "We'll come somewhere; it shouldn't be too hard. I think } \\
\text { it would be a bigger problem to get used to social life or } \\
\text { not to get used to the concept we call order." }\end{array}$ \\
\hline $\begin{array}{l}\text { The environmental factors will affect } \\
\text { the success and social life of these } \\
\text { young people (7) }\end{array}$ & $\begin{array}{l}\text { "I think it can change a lot depending on the style of } \\
\text { upbringing. But I have little idea about my future, } \\
\text { because it is not clear what the system will do." }\end{array}$ \\
\hline $\begin{array}{l}\text { Their own efforts are also required to } \\
\text { differentiate }(7)\end{array}$ & $\begin{array}{l}\text { "If individuals can educate themselves, their future is } \\
\text { bright and they can be in the most prestigious places in } \\
\text { the future." }\end{array}$ \\
\hline $\begin{array}{l}\text { Shouldn't have more expectations from } \\
\text { other individuals - like normal people } \\
\text { (10) }\end{array}$ & $\begin{array}{l}\text { "I think that if they discover their talented areas, they can } \\
\text { take a very important place in society and this is no } \\
\text { different from a normal person." }\end{array}$ \\
\hline $\begin{array}{l}\text { They have a bright future if they utilize } \\
\text { their own capacities / abilities (8) }\end{array}$ & $\begin{array}{l}\text { "If they improve their capacity, they can be more } \\
\text { comfortable and relaxed." }\end{array}$ \\
\hline
\end{tabular}

When Table 5 is examined, the most emphasized theme from the point of view of gifted individuals is that they will be successful in any situation (36) and that they will be successful in their own lives with sufficient support (31). The least recurring theme is that gifted individuals' own efforts to differentiate are also very important (7) and environmental factors will play an important role in their social life (7). In this context, we can say that gifted students' expectations for their own future are mostly positive.

\section{Findings from the Answers of the Gifted Participants}

"What do you think about the future of gifted individuals?" The answers given by the adult participants to the question were examined and sample answers regarding the reached themes are presented in Table 6. 
Table 6. Sample Answers and Themes About Expectations of Gifted Students for Their Future

\begin{tabular}{l|l}
\hline $\begin{array}{l}\text { Successful with adequate support } \\
\text { (56) }\end{array}$ & $\begin{array}{l}\text { "If they gets a good education appropriate to their talent, their } \\
\text { future will be very bright. Otherwise, they may be insatiable } \\
\text { individuals who are incompatible with society and whose } \\
\text { expectations are not met." }\end{array}$ \\
\hline $\begin{array}{l}\text { Unconditionally successful (26) } \\
\text { Hopeless due to the conditions } \\
\text { (33) }\end{array}$ & $\begin{array}{l}\text { "I think they can have a good family and social life ahead of } \\
\text { these individuals are aware of this and their perceptions are } \\
\text { very clear, they aim the countries as the future, where they can } \\
\text { give this value to themselves and receive their work fairly and } \\
\text { honestly." }\end{array}$ \\
\hline $\begin{array}{l}\text { Although they are successful, } \\
\text { there will be problem about their } \\
\text { social development and } \\
\text { adaptation (11) }\end{array}$ & $\begin{array}{l}\text { "They will surely be more successful than other people in their } \\
\text { work. However, the biggest handicaps of most of them arise in } \\
\text { socialization. So the earlier they are discovered, the better their } \\
\text { chances." }\end{array}$ \\
\hline $\begin{array}{l}\text { They have a bright future if they } \\
\text { utilize their own capacities / } \\
\text { abilities (8) }\end{array}$ & $\begin{array}{l}\text { "A happy and peaceful light in which they can improve and be } \\
\text { useful." }\end{array}$ \\
\hline
\end{tabular}

In Table 6, when adults' perspectives on the future of Gifted Individuals are examined, the most common theme is that they will be successful if they get enough support (56) and the least common theme is that they will have a bright future if they evaluate their potential (8). In this sense, we can say that adults mostly attribute the success of gifted students to the support they will receive.

\section{DISCUSSION, CONCLUSION AND SUGGESTIONS}

When we look at the results of the study, the answers of both adults and individuals with high potential are that the professions in the fields of science, medicine, health, $R \& D$ and engineering predict the future of individuals with high potential. In this sense, gifted students are perceived as more researcher type people. When the literature in our country is examined, according to the results of Kaya et all. (2015) study examining the profession choices of gifted students; they prefer engineering, medicine, design, science, defense, space science, law and business. In addition, according to Sunar et al.'s booklet research published in 2020, it is stated that professions such as medicine, judge, professor, electrical engineer, pilot are among those with the highest professional reputation. In this context, we can say that the result of our research has many similarities with the existing literature. In addition, it is known that the family, namely adults, has an influence and support in choosing a profession (Gati \& Tal, 2008). Families' expectations play a role in the evolution of students' professional preferences over time, so it is seen that the expectations of adults and gifted students are parallel. This perception may have affected the perception and responses of gifted individuals. These results show that the tendency to have prestigious professions in society is important regardless of age group and expectations of people are generally in this direction.

On the other hand, the area of potential for both adults and gifted students is one of the most important criteria in choosing a profession, and the participants stated that young people should be guided in this direction. The choice of profession occurs over the years, and the school and the environment play a major role in revealing students' interest and ability in the formation process (Vurucu, 2010). The choice of 
profession to be made in the field of potential will play a role in the individuals to do their job better and to be successful (Campbell et al., 2011). In this context, the participants may have made comments in parallel with the literature, considering that future job performance will affect success, gain and satisfaction. The participants who gave us this result show that people think that the success achieved with the profession will directly affect the happiness and satisfaction, and even increase the quality of life.

Considering all the answers about the education of gifted students, which is the second question, it can be said that the participants are worried about the quality of the education and they support an outside touch in order for the students to discover their talent areas. Today, global changes that direct the whole society make questioning the quality of education inevitable for all students (Krneta, 2016). While global events cause people to look to the future uncertainly, they also cause them to question education. In addition, as a result of a study conducted with gifted high school students, it was found that nearly half of the youth experienced indecision in terms of professional choice and therefore it was extremely important to receive individualized counseling (Leung, 1998). There are also studies confirming the reasons why individuals are concerned about this issue. In a study conducted by Chen (2013), it was emphasized that gifted children sometimes suffer from issues related to their social, emotional and professional development, and these issues should be addressed within their schools and the environment they live in. It seems that the data we have and the literature are parallel for years. In this study, adults may also have made this inference based on their own educational processes and today's educational support they observed. As stated in the literature, we can conclude that the students gave answers seeking support from outside because they could not overcome their indecision on their own. These answers show us that individuals with giftedness are open to direction.

Considering the last question, the perception of the future, although there are answers that the participants are hopeless, it is predicted that these students will be successful when the necessary conditions of the general perception are met or unconditionally. According to the results of a study conducted with 688 standards and students who are considered to be gifted in this regard; the results in perception of the future are very similar for both groups, and there were not very pessimistic and weak results from the participants; It has been observed that nearly half of the participants perceive their future as beautiful (Krneta, 2016). Existing conditions were identified as a factor that discouraged the participants. However, we can say that individuals' potential is trusted and despite everything, they expect positive results in the future.

In recent years, we have been receiving many initiatives and training for the development of Gifted Individuals, for example The Gifted Education Programs (ÜYEP), founded by Prof. Dr. Uğur Sak, is a program established with criteria such as creating original curricula and training of educators, taking into account the development of students in primary and secondary education (Tortop, 2015). In addition, the Gifted University Bridge Education Program (ÜYÜKEP) is an important step taken by Assoc. Dr. Said Tortop in the university leg (Tortop, 2015). In addition, it was found in the Council of Higher Education Thesis Website that 164 theses were made about gifted students in the last 10 years. These results show that there is a need and a tendency to work intensively in this area. In general, various studies are carried out on gifted youth in our country, but they do not support the population of the sample studied in the studies with official data. Researchers are carrying out their research with Science and Art Centers and institutions that currently provide education to gifted students. Since institutions do not have common criteria for accepting students, the samples created by the researchers may vary. In order to increase the quality of the researches and to offer concrete suggestions, it is necessary to draw the framework of the studies on gifted students. In addition, it is seen that the studies conducted are generally studies examining academic success. It needs to see how our country directs this potential and to do studies. In this context, longitudinal studies will draw us a clearer picture. 


\section{REFERENCES}

Bryant, C. D. (2010). High school principals' attitudes toward and perceptions of gifted students and gifted programs (Doctoral dissertation). Retrieved from ProQuest Dissertations (Order No: 3465682).

Campbell, D. P., \& Holland, J. L. (1972). A merger in vocational interest research: Applying Holland's theory to Strong's data. Journal of Vocational Behavior, 2(4), 353-376. DOI:10.1016/0001-8791(72)90012-7

Chen, C. P., \& Wong, J. (2013). Career counseling for gifted students. Australian Journal of Career Development, 22(3), 121-129. DOI:10.1177/1038416213507909

Gati, I., \& Tal, S. (2008). Decision-making models and career guidance. J. A. Athanasou and $\quad$ R. Van Esbroeck (Eds.). International handbook of career guidance, 157-185. DOI: https://doi.org/10.1007/978-14020-6230-8_8

Holland, J. L. (1973). Making vocational choices: A theory of careers. Englewood Cliffs, NJ: Prentice-Hall. Retrieved from http://garfield.library.upenn.edu/classics1980/A1980JR23200001.pdf

Jolly, J. L., \& Matthews, M. S. (2012). A critique of the literature on parenting gifted learners. Journal for the Education of the Gifted, 35(3), 259-290. DOI: https://doi.org/10.1177/0162353212451703

Kılıç, V. C. (2015). Türkiye'de üstün ve özel yetenekli çocuklara yönelik bir eğitim politikası oluşturulamaması sorunu üzerine bir değerlendirme. 21. Yüzyılda Eğitim ve Toplum Eğitim Bilimleri ve Sosyal Araştırmalar Dergisi, 4(12), 145-154.

Sunar, L., Koytak, M. E., \& Esen, M. F. (2020). Türkiyede çalışma hayatı ve meslekler-Toplumsal Yapı Araştırmaları Programı 1. İstanbul: Limit Ofest.

Krneta, D. L. (2016). Perception of present and vision of future of gifted students. Universal Journal of Educational Research, 4(8), 1745-1752. DOI: 10.13189/ujer.2016.040801

Kuzgun, Y. (2014). Meslek gelişimi ve danışmanlığı. Ankara: Nobel Akademik Yayıncılık.

Lens, W., \& Rand, P. (2000). Motivation and cognition: Their role in the development of giftedness. International handbook of giftedness and talent, (2nd ed), Oxford, England: Elsevier, pp: 193-202.

Leung, A. S. (1998). Vocational identity and career choice congruence of gifted and talented high school students. Counseling Psychology Quarterly, 11(3), 325-335. DOI: https://doi.org/10.1080/09515079808254064

MEB (2016). Bilim ve sanat merkezleri yönergesi. Millî Ĕ̆gitim Bakanlı̆̆g Tebliğler Dergisi, $\quad$ 79, $\quad$ 449-473. Retrieved from https://orgm.meb.gov.tr/meb_iys_dosyalar/2017_01/02031535_tebligler_dergisi.pdf

Miller, S. (2003). Analysis of phenomenological data generated with children as research participants. Nurse Researcher, 10(4), 68-82. DOI: 10.7748/nr2003.07.10.4.68.c5908

National Association for Gifted Children (2020). What is Giftedness: Information for the public. Retrieved from https://www.nagc.org/resources-publications/resources/what-giftedness

Ogurlu, U. (2016). Hopelessness and future expectations among gifted middle school students. Turkish Journal of Education, 5(1), 4-17 DOI: https://doi.org/10.19128/turje.30206

Sarıoğlu Uğur, S., \& Devcar, M. (2018). Girişimcilik özellikleri ile Holland'in kişilik tipleri arasindaki ilişki üzerine nitel bir çalışma. Girişimcilik Inovasyon ve Pazarlama Araştırmaları Dergisi, 2(4), 98-110. DOI: 10.31006/gipad.397013

Stemler, S. (2001). An overview of content analysis. Practical Assessment, Research \& Evaluation, 7(17), 137-146. DOI: https://doi.org/10.7275/z6fm-2e34

Tortop, H. S., \& Ersoy, B. (2015). Üstün yetenekliler üniversite köprüsü eğitim programına (ÜYÜKEP) katilan üstün yetenekli öğrencilerin sınıf öğretmenlerinin ÜYÜKEP hakkindaki görüşleri. Journal of Gifted Education and Creativity, 2(1), 17-24. DOI: 10.18200/JGEDC.2015111170. 
Uzun, A. (2006). Üstün veya özel yetenekli öğrencilerin sosyal bilgiler dersine ilişkin tutumları ile akademik başarıları arasındaki ilişki (Doktora Tezi). DEÜ Eğitim Bilimleri Enstitüsü. Retrieved from http://acikerisim.deu.edu.tr:8080/xmlui/bitstream/handle/20.500.12397/7504/188921.pdf?sequence=1

Unsal, P. (2014). Kariyer gelişim kuramları ve kariyer danıșmanlıgı (1.Baskı). Ankara: Nobel Akademik Yayıncilik.

Kaya, F., Ogurlu, U., \& Hizlı, E. (2017). Career decisions of gifted students in Turkey. Journal of European Education, l(5), 35-51. DOI:10.18656/JEE.86698

Vurucu, F. (2010). Meslek lisesi öğrencilerinin meslek seçimi yeterliliği ve meslek seçimini etkileyen faktörler (Yayınlanmamış Yüksek Lisans Tezi). Yeditepe Üniversitesi Sosyal Bilimler Enstitüsü, Retrieved from https://toad.halileksi.net/sites/default/files/pdf/meslek-seciminde-yeterlilik-olcegi-toad.pdf

Van Iddekinge, C. H., Putka, D. J., \& Campbell, J. P. (2011). Reconsidering vocational interests for personnel selection: The validity of an interest-based selection test in relation to job knowledge, job performance, and continuance intentions. Journal of Applied Psychology, 96(1), 1333. DOI:10.1037/a0021193

Wood, S. (2006). Gifted and talented adolescents' experiences in school counseling (Master thesis). Available from W\&M ScholarWorks (Order No. 1550154194). https://dx.doi.org/doi:10.25774/w4-ek3z-z928 